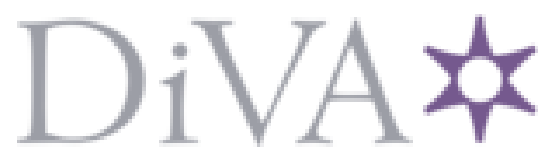

http://www.diva-portal.org

This is the published version of a paper published in Stem Cells and Development.

Citation for the original published paper (version of record):

Kingham, P., Kolar, M., Novikova, L., Novikov, L., Wiberg, M. (2013)

Stimulating the neurotrophic and angiogenic properties of human adipose-derived stem cells enhances nerve repair.

Stem Cells and Development

http://dx.doi.org/10.1089/scd.2013.0396

Access to the published version may require subscription.

N.B. When citing this work, cite the original published paper.

Permanent link to this version:

http://urn.kb.se/resolve?urn=urn:nbn:se:umu:diva-83708 


\title{
Stimulating the Neurotrophic and Angiogenic Properties of Human Adipose-Derived Stem Cells Enhances Nerve Repair
}

\author{
Paul J. Kingham, ${ }^{1}$ Mallappa K. Kolar, ${ }^{1,2}$ Liudmila N. Novikova, ${ }^{1}$ Lev N. Novikov, ${ }^{1}$ and Mikael Wiberg ${ }^{1,2}$
}

In future, adipose-derived stem cells (ASC) might be used to treat neurological disorders. In this study, the neurotrophic and angiogenic properties of human ASC were evaluated, and their effects in a peripheral nerve injury model were determined. In vitro growth factor stimulation of the cells resulted in increased secretion of brain-derived neurotrophic factor (BDNF), glial cell-derived neurotrophic factor (GDNF), vascular endothelial growth factor-A (VEGF-A), and angiopoietin-1 proteins. Conditioned medium from stimulated cells increased neurite outgrowth of dorsal root ganglia (DRG) neurons. Similarly, stimulated cells showed an enhanced ability to induce capillary-like tube formation in an in vitro angiogenesis assay. ASC were seeded into a fibrin conduit that was used to bridge a $10 \mathrm{~mm}$ rat nerve gap. After 2 weeks, the animals treated with control or stimulated ASC showed an enhanced axon regeneration distance. Stimulated cells evoked more total axon growth. Analysis of regeneration and apoptosis-related gene expression showed that both ASC and stimulated ASC enhanced GAP-43 and activating transcription factor 3 (ATF-3) expression in the spinal cord and reduced c-jun expression in the DRG. Caspase-3 expression in the DRG was reduced by stimulated ASC. Both ASC and stimulated ASC also increased the vascularity of the fibrin nerve conduits. Thus, ASC produce functional neurotrophic and angiogenic factors, creating a more desirable microenvironment for nerve regeneration.

\section{Introduction}

Successful RePair of injured peripheral nerves remains a Serious clinical challenge, especially in the case of nerve tissue loss, when a simple direct repair is not feasible due to the gap created between the transected nerve ends [1,2]. The current clinical gold standard for such injuries is to use an autologous nerve graft, but this creates donor site morbidity with loss of sensation and consequent scarring. Thus, there is great interest to engineer new nerve tissue constructs that will enable regenerating peripheral axons to cross the gap, innervate the distal stump, and reconnect target organs. Nerve guidance conduits have been produced from a range of materials and may incorporate various forms of surface topographies, intraluminal structures to promote alignment of axons, and different technologies to release growth factors [3-5]. Addition of cells to these structures can be used to enhance their effectiveness. Schwann cells, the endogenous mediator cells of the peripheral nervous system [6], are an obvious choice and have shown significant benefits but these are likely to be out-weighed by the requirement for large numbers of cells that need to be harvested from other healthy nerves. Thus, stem cell therapy for the damaged peripheral nervous system has recently gained favor [7].

There are numerous different stem cell types but optimally, the cells should be easily accessible, grow rapidly and in a controlled manner in vitro, be capable of modulating the immune reaction, and when transplanted in vivo, survive and contribute to new tissue formation [8]. Both embryonic (ESC) and adult tissue-derived stem cells have been shown to differentiate into neural progenitor phenotypes that can promote nervous system regeneration [8], but widespread use of ESC is unlikely given the ethical issues concerning their derivation. Adipose-derived stem cells (ASC) have multi-lineage (mesodermal and possibly ectodermal and endodermal) differentiation potential [9] and show a number of distinct advantages compared with other adult stem cell types. Adipose tissue is easily accessible via liposuction or abdominoplasty and has been shown to contain a higher number of stem cells/progenitors than bone marrow tissue [10]. The extracted cells also expand more rapidly than those from other tissues [11]. We and other groups have shown

\footnotetext{
${ }^{1}$ Section for Anatomy, Department of Integrative Medical Biology, Umeå University, Umeå, Sweden.

${ }^{2}$ Section for Hand and Plastic Surgery, Department of Surgical \& Perioperative Science, Umeå University, Umeå, Sweden.
} 
that rat ASC can be differentiated toward a Schwann cell-like phenotype which promotes neurite outgrowth [12-16] and myelination [16-18]. In addition to their ability to differentiate, ASC can secrete a plethora of growth factors that can mediate angiogenesis, wound healing, tissue regeneration, and immune cell reactions $[19,20]$. In the context of nervous system regeneration, it has been shown that ASC produce a wide variety of neurotrophic factors which can enhance neurite outgrowth and provide neuroprotection [12,21-24].

Transplantation of rat ASC in nerve conduits promotes nerve regeneration, enhances nerve conduction velocities, and reduces muscle atrophy and sensory neuron cell death after sciatic nerve injury [25-30]. To date, only a few reports show these results can be replicated using human ASC. The aim of this study was, therefore, to determine the neurotrophic and angiogenic potential of human ASC in response to a defined stimulation protocol and what effects this might have on the ASC ability to enhance nerve repair in vivo.

\section{Materials and Methods}

\section{Cell culture}

ASC were isolated from human abdominal fat from patients undergoing elective surgeries. All procedures were approved by the Local ethics committee for Clinical Research in Umeå University (No. 03-425). Adipose tissue was minced, digested with $0.15 \%(\mathrm{w} / \mathrm{v})$ type I collagenase, and centrifuged as previously described [22]. The final stromal fraction pellet containing stem cells was resuspended in growth medium; $\alpha$-minimum essential media ( $\alpha$-MEM), $10 \%$ $(\mathrm{v} / \mathrm{v})$ fetal calf serum, and $1 \%(\mathrm{v} / \mathrm{v})$ penicillin/streptomycin (all from Invitrogen) and plated onto a $75 \mathrm{~cm}^{2}$ tissue culture flask. Cells were kept at $37^{\circ} \mathrm{C}$ and $5 \% \mathrm{CO}_{2}$. The flask was washed with Hank's balanced salt solution (HBSS) every $24 \mathrm{~h}$ for 5 days to eliminate hematopoietic cells, and then, fresh growth medium was added. On reaching 90\% confluence, the cells were passaged to new culture flasks by using tryp$\sin /$ EDTA and plated at a density of 5,000 cells $/ \mathrm{cm}^{2}$.

\section{Characterization of the cells}

To define the isolated cells as a non-hematopoietic and stromal/stem cell population, ASC at passage 2 were plated onto Labtek ${ }^{\mathrm{TM}}$ eight-well chamber slides at a density of $5 \times 10^{4}$ cells $/ \mathrm{mL}$. After fixation with $4 \%(\mathrm{w} / \mathrm{v})$ paraformaldehyde, immunolabeling was performed with a Mesenchymal Stem Cell Characterization Kit (Millipore). Antibodies were used according to the manufacturer's instructions and included hematopoietic cell markers CD14, CD19, as well as stromal/stem cell markers, CD54, CD90, CD105, CD146, and HCAM. The multi-potency of the ASC was demonstrated by the differentiation into osteogenic and adipogenic lineages as previously described [15].

\section{Cell stimulation}

To stimulate an enhanced neurotrophic and angiogenic phenotype, ASC were treated as previously described for rat cells [15]. The growth medium was replaced with fresh medium containing $1 \mathrm{mM} \beta$-mercaptoethanol and cultured for $24 \mathrm{~h}$. Fresh medium containing $35 \mathrm{ng} / \mathrm{mL}$ all-trans-retinoic acid was replaced for $72 \mathrm{~h}$. Subsequently, the cells were washed with HBSS and the medium was replaced by stimulation medium that consisted of growth medium with $200 \mathrm{ng} / \mathrm{mL}$ neuregulin1-beta1 (R\&D Systems), $10 \mathrm{ng} / \mathrm{mL}$ basic fibroblast growth factor (bFGF; Milipore), $5 \mathrm{ng} / \mathrm{mL}$ platelet-derived growth factor (PDGF-AA; Millipore), and $14 \mu \mathrm{M}$ forskolin (Sigma). Fresh stimulation medium was added every $72 \mathrm{~h}$ over a period of 2 weeks, and cells were passaged once they became $90 \%$ confluent. Cultures of unstimulated cells were always run in parallel. Experiments studying conditioned media (CM) effects were started after this first 2 week period of expansion, and cells were freshly plated and stimulated with factors. Cells for in vivo transplantation were also obtained after the 2 weeks' growth period and freshly stimulated for $48 \mathrm{~h}$ before transplantation.

\section{Semi-quantitative RT-PCR}

RT-PCR was performed to measure mRNA expression levels of neurotrophic and angiogenic molecules. Total RNA was isolated from human ASC (passages 2-4) using an RNeasy ${ }^{\mathrm{TM}}$ kit (Qiagen), and then, 1 ng RNA was incorporated into the One-Step RT-PCR kit (Qiagen) as per reaction mix. Primers were manufactured by Sigma (Table 1). A thermocycler (Biometra) was used with the following parameters: a reverse transcription step $\left(50^{\circ} \mathrm{C}, 30 \mathrm{~min}\right)$, a nucleic acid

Table 1. Primer Sequences for RT-PCR and Annealing Temperatures Used

\begin{tabular}{lllr}
\hline Factor & \multicolumn{1}{c}{ Forward primer $\left(5^{\prime} \rightarrow 3^{\prime}\right)$} & \multicolumn{1}{c}{ Reverse primer $\left(5^{\prime} \rightarrow 3^{\prime}\right)$} & Annealing temperature $\left({ }^{\circ} \mathrm{C}\right)$ \\
\hline NGF & ATACAGGCGGAACCACACTCAG & GTCCACAGTAATGTTGCGGGTC & 64.0 \\
BDNF & AGAGGCTTGACATCATTGGCTG & CAAAGGCACTTGACTACTGAGCATC & 64.0 \\
GDNF & CACCAGATAAACAAATGGCAGTGC & CGACAGGTCATCATCAAAGGCG & 55.9 \\
NT3 & GGGAGATCAAAACGGGCAAC & ACAAGGCACACACACAGGAC & 62.0 \\
VEGF-A & ATCTGCATGGTGATGTTGGA & GGGCAGAATCATCACGAAG & 60.2 \\
ang-1 & CTTGACCGTGAATCTGGAGC & AGCAAGACATAACAGGGTGAG & 59.7 \\
GAP-43 & GTCCACTTTCCTCTCTATTTC & TGTTCATTCCATCACATTGA & 55.0 \\
ATF-3 & GACTGGTATTTGAAGCCAGGAGTG & GGACCGCATCTCAAAATAGC & 63.0 \\
c-jun & TGGGCACATCACCACTACAC & AGTTGCTGAGGTTGGCGTA & 60.8 \\
casp-3 & GGACCTGTGGACCTGAAAAA & AGTTCGGCTTTCCAGTCAG & 60.5 \\
$18 S$ & TCAACTTTCGATGGTAGTCGC & CCTCCAATGGATCCTCGTTAA & 61.9 \\
\hline
\end{tabular}

BDNF, brain-derived neurotrophic factor; GDNF, glial cell-derived neurotrophic factor; VEGF-A, vascular endothelial growth factor-A; NGF, nerve growth factor; NT3, neurotrophin 3; ATF-3, activating transcription factor 3; ang-1, angiopoietin-1; GAP-43, growth associated protein 43; casp-3, caspase-3. 
denaturation/reverse transcriptase inactivation step $\left(95^{\circ} \mathrm{C}\right.$, $15 \mathrm{~min}$ ) followed by $28-34$ cycles of denaturation $\left(95^{\circ} \mathrm{C}, 30 \mathrm{~s}\right)$, annealing (30 s, optimized per primer set as described in Table 1 ), and primer extension $\left(72^{\circ} \mathrm{C}, 1 \mathrm{~min}\right)$ followed by final extension incubation $\left(72^{\circ} \mathrm{C}, 5 \mathrm{~min}\right)$. PCR amplicons were electrophoresed $(50 \mathrm{~V}, 90 \mathrm{~min})$ through a $1.5 \%(\mathrm{w} / \mathrm{v})$ agarose gel, and the size of the PCR products was estimated using Hyperladder IV (Bioline). Samples were visualized under UV illumination following GelRed ${ }^{\mathrm{TM}}$ nucleic acid stain (BioNuclear Sweden) incorporation into the agarose.

\section{Enzyme-linked immunosorbant assay}

ASC $\left(1.25 \times 10^{5}\right)$ were seeded into 96-well plates and maintained for $48 \mathrm{~h}$. The supernatant was then collected and analyzed by ELISA using the ChemiKine ${ }^{\mathrm{TM}}$ BDNF sandwich ELISA kit (Millipore) or NGF, GDNF, angiopoietin-1, and VEGF-A sandwich ELISA kits (RayBiotech, Inc.) according to the manufacturer's protocol. All samples were analyzed in triplicate, and the absorbance was measured at $450 \mathrm{~nm}$ on a SpectraMax190 microplate reader (Molecular Devices, Inc.). The quantity of neurotrophic and angiogenic factors $(\mathrm{pg} / \mathrm{mL})$ was calculated against standard curves that were produced using recombinant proteins provided in the kits and normalized to the final number of cells counted after $48 \mathrm{~h}$ of incubation.

\section{In vitro neurite outgrowth assay}

Dorsal root ganglia (DRG) neurons were harvested from 7to 8-week-old Sprague-Dawley rats as previously described [12]. The DRG neurons were plated on sterile $12 \mathrm{~mm}$ circular coverslips in triplicate that were placed in a $35 \mathrm{~mm}$ Petri dish. ASC at a density of $1.25 \times 10^{5}$ cells $/ \mathrm{mL}$ were plated on six-well plates in control or stimulation medium. CM from these wells were collected at $48 \mathrm{~h}$, centrifuged at $650 \mathrm{~g}$ for $10 \mathrm{~min}$ to remove any floating cells, and then, $1 \mathrm{~mL}$ of the supernatant were applied directly to the Petri dishes containing DRGs, which had been plated $24 \mathrm{~h}$ earlier. CM and DRG co-cultures were maintained in the incubator for $24 \mathrm{~h}$ before the DRGs were fixed with $4 \%$ paraformaldehyde and immunostained with $\beta I I I-$ tubulin antibody (1:500; Sigma) as previously described [12]. The resulting slides were observed with an ECLIPSE 90i microscope, and images were captured with Nikon Elements Imaging software (Nikon). The neurite outgrowths of $\beta I I I-$ tubulin-positive DRG were manually traced with Image ProPlus software (MediaCybernetics). The mean longest neurite length and total neurite outgrowth were determined.

\section{In vitro angiogenesis assay}

An in vitro angiogenesis assay kit (Millipore) was used for evaluation of tube capillary-like formation by endothelial cells. When cultured on ECMatrix ${ }^{\mathrm{TM}}$, a solid gel of basement proteins prepared from the Engelbreth Holm-Swarm mouse tumor, endothelial cells rapidly align and form hollow tubelike structures. ECMatrix was prepared in 96-well plates as described by the manufacturer, and $5 \times 10^{3}$ human umbilical vein endothelial cells (HUVEC; Invitrogen) were plated onto the surface in the presence of CM from ASC. Since we found that factors used to stimulate ASC interfered with the assay, we first stimulated the ASC for $24 \mathrm{~h}$, then washed the cells four times with HBSS to remove stimulating factors, and reapplied regular growth medium for $48 \mathrm{~h}$. HUVECs were al- lowed to attach for $4 \mathrm{~h}$ before tube formation was evaluated by light microscopy. Four random fields from each well were captured and analyzed for total network length (continuously joined end-end cells) and the number of closed polygon-shaped structures. These values were used as a semi-quantitative measure of angiogenesis as recommended by the manufacturer.

\section{Conduit preparation and surgical procedure}

Tubular fibrin conduit was molded from two compound fibrin glue (Tisseel $\urcorner$ Duo Quick; Baxter). All components were mixed in sterile conditions, and a silicone mold with a centrally placed metal rod was used to prepare tubular 14-mm-long conduits with uniform 1-mm-thick walls and $2 \mathrm{~mm}$ lumen as previously described [26]. After glue polymerization, the rods and silicone mold were removed, and fibrin glue conduits were loaded with fibrin matrix with or without ASC. Fibrin matrix was produced by modifying the fibrin glue as previously described [31]. ASC or stimulated ASC cultured in parallel for 2 weeks were re-suspended with the diluted fibrinogen solution $\left(2 \times 10^{6} / 20 \mu \mathrm{L}\right)$. The diluted thrombin solution $(20 \mu \mathrm{L})$ was injected into the lumen of a conduit and then, immediately the cell/fibrinogen suspension was added. The matrix was allowed to polymerize before surgical transplantation into the sciatic nerve defect.

Transplantation experiments were performed on adult (10-12 weeks) female Sprague-Dawley rats (Taconic Europe $\mathrm{A} / \mathrm{S})$. The animal care and experimental procedures were carried out in accordance with the Directive 2010/63/EU of the European Parliament and of the Council on the protection of animals used for scientific purposes and was also approved by the Northern Swedish Committee for Ethics in Animal Experiments (No. A186-12). All surgical procedures were performed under general anesthesia using a mixture of ketamine (100 mg/kg i.v., Ketalar $\urcorner$; Parke-Davis) and xylazine (10 mg/kg i.v., Rompun $\urcorner$; Bayer;). After surgery, the rats were given the analgesic Finadyne $(2.5 \mathrm{mg} / \mathrm{kg}$, s.c.; ScheringPlough;), normal saline (4 $\mathrm{mL}$ s.c.), and benzylpenicillin (Boehringer Ingelheim; $60 \mathrm{mg}$ i.m.). Each animal was housed alone in a cage after surgery and exposed to 12-h light/dark cycles, with free access to food and water.

Under an operating microscope (Carl Zeiss), the sciatic nerve was exposed and then divided $5 \mathrm{~mm}$ below the exit point from sciatic notch and $5 \mathrm{~mm}$ of sciatic nerve distal to the division was removed creating a $10 \mathrm{~mm}$ gap. The $14 \mathrm{~mm}-$ long fibrin conduit was inserted in the gap, allowing for intubation of the proximal and distal nerve ends $2 \mathrm{~mm}$ into the conduit. The conduits with ASC $(n=7)$ were fixed to the epineurium with two 10.0 Ethilon sutures at each end. The wound was then closed in layers. The control group comprised fibrin conduits containing fibrin matrix alone (no cells; $n=7)$. Animals were allowed to survive for 2 weeks and were treated daily with cyclosporine A (CsA, Sandimmun; Novartis) that was injected sub-cutaneously at $1.5 \mathrm{mg}$ per $100 \mathrm{~g}$ body weight, administered starting from $24 \mathrm{~h}$ before surgery.

\section{Measurement of regeneration}

At the end of the survival period, the animals were given an overdose of sodium pentobarbital $(240 \mathrm{mg} / \mathrm{kg}$, i.p.; Apoteksbolaget) and ipsi-lateral L4-L6 DRG, and spinal cord segments were harvested and rapidly frozen with liquid 
nitrogen for future molecular analysis. The conduit was also harvested and fixed with $4 \%(\mathrm{w} / \mathrm{v})$ paraformaldehyde followed by embedding in OCT medium. Immunostaining was performed on longitudinal $16-\mu \mathrm{m}$-thick sections of fibrin conduits. After blocking with normal serum, mouse anti$\beta I I I-t u b u l i n$ antibody (1:500; Sigma-Aldrich), mouse antihuman nuclei antibody (1:100; Millipore), rabbit anti-S100 protein (1:2,000; Dako), or mouse anti-RECA-1 antibody (1:25; Abcam) were applied for $2 \mathrm{~h}$. After rinsing in phosphatebuffered solution, secondary Alexa Fluor 488-conjugated goat anti-mouse IgG or Alexa Fluor 568-conjugated goat anti-rabbit IgG (1:300; Molecular Probes) was applied for $1 \mathrm{~h}$ at room temperature in the dark. The slides were cover slipped with ProLong anti-fade mounting medium containing 4'-6-diamido2-phenylindole (DAPI; Invitrogen). Axon regeneration distance was measured using an optical microgrid; the length was measured from the beginning of the proximal nerve stump to the last visible sprout of the regenerating front. Every sixth to eighth section was first scanned under the microscope to identify the sections containing the longest axons, and then, four sections within the selected range were used for analysis. In addition, beginning at $2 \mathrm{~mm}$ distal to the end of the proximal stump (where individual axons could be distinguished), axonal profiles were counted in a line perpendicular to the direction of the conduit in serial, high power fields distally every $500 \mu \mathrm{m}$ until the field contained no more positive $\beta \mathrm{III}-$ tubulin staining. The number of RECA-1-positive capillary structures was also counted from eight random fields/slides obtained from the mid-point of the conduits.

\section{qRT-PCR of nerve tissue}

One nanogram of total RNA per reaction was converted into cDNA using the iScript ${ }^{\mathrm{TM}}$ cDNA synthesis kit (Bio-Rad). qRT-PCR was performed using SsoFast ${ }^{\mathrm{TM}}$ EvaGreen supermix (Bio-Rad) in a CFX96 Optical Cycler and analyzed using the CFX96 manager software (Bio-Rad). Primers were manufactured by Sigma (Table 1), and reactions were optimized and processed according to the manufacturer with initial denaturation/DNA polymerase activation at $95^{\circ} \mathrm{C}$ for $30 \mathrm{~s}$ followed by PCR: $95^{\circ} \mathrm{C}$ for $5 \mathrm{~s}$, variable annealing temperature (see Table 1 ) for $5 \mathrm{~s}$, and $65^{\circ} \mathrm{C}$ for $5 \mathrm{~s}$ repeated for 40 cycles. $18 \mathrm{~S}$ was used as a housekeeping gene. Data were calculated as relative expressions according to the $\Delta \mathrm{C}(\mathrm{t})$ principle.

\section{Statistical analysis}

Mean \pm standard errors of the mean were calculated for all data. One-way analysis of variance (ANOVA) followed by a post hoc Newman-Keuls test (Prism $\urcorner$; Graph-Pad Software, Inc.) was used to determine statistical differences between experimental groups. Statistical significance was set as ${ }^{*} P<0.05,{ }^{* *} P<0.01$, and ${ }^{* * *} P<0.001$.

\section{Results}

\section{Stem cell characterization}

ASC were isolated from three patients undergoing elective abdominoplasty (all female, mean age $44 \pm 3$ years) and expanded in vitro. The adherent cells were immunostained at passage 2 for a variety of cell surface markers (Fig. 1A-G). The cultures were negative for both CD14 (present on leu- kocytes) and CD19 (present on B-lymphocytes) and positive for the general mesenchymal stem cell markers CD54, CD90, CD105, CD146, and HCAM (CD44). Cells from each patient could be efficiently differentiated along the osteogenic and adipogenic lineages as evidenced by Alizarin red positive calcium staining (Fig. $1 \mathrm{H}$ ) and Oil Red $\mathrm{O}$ reactive lipid droplets (Fig. 1I), respectively.

\section{Stimulation of ASC enhances neurotrophic and angiogenic properties in vitro}

Stem cells were stimulated with a mixture of growth factors (forskolin, bFGF, PDGF-AA, and neuregulin1- $\beta 1$ ) for a period of 2 weeks. Semi-quantitative RT-PCR analysis showed that the stimulation protocol enhanced the expression of the neurotrophic factors, nerve growth factor (NGF), brain-derived neurotrophic factor (BDNF), and glial cellderived neurotrophic factor (GDNF) but down-regulated the expression of neurotrophin 3 (NT3) (Fig. 2A). ELISA analysis indicated that increased mRNA levels correlated with enhanced secretion of BDNF and GDNF protein (Fig. 2B). Stimulation of the cells resulted in the release of $101.70 \pm 14.45 \mathrm{pg} / \mathrm{mL}$ BDNF and $18.79 \pm 3.27 \mathrm{pg} / \mathrm{mL}$ GDNF, both of which were significantly $(P<0.01)$ higher than the corresponding protein levels secreted by unstimulated cells. The expression levels of the angiogenic molecules, vascular endothelial growth factor-A (VEGF-A), and angiopoietin-1 were also increased (Fig. 2C). Secreted angiopoietin-1 levels were significantly $(P<0.001)$ increased from $5.11 \pm 0.77 \mathrm{ng} /$ $\mathrm{mL}$ in unstimulated cells to $17.63 \pm 1.33 \mathrm{ng} / \mathrm{mL}$ in stimulated cells (Fig. 2D). Unstimulated ASC released high levels of VEGF-A $(20.92 \pm 3.54 \mathrm{ng} / \mathrm{mL})$, but this could also be further increased with the stimulation protocol (Fig. 2D).

Next, in vitro assays for neurite outgrowth and angiogenesis were used to determine whether the increased levels of the growth factors had some functional consequences. Rat DRG neurons were seeded onto coverslips and after $48 \mathrm{~h}$, they were immunostained with $\beta$ III-tubulin antibody to measure neurites. Neurons seeded in medium conditioned by ASC or stimulated ASC extended a number of long neurites that were absent in the DRG neuron cultures exposed to the respective media controls alone (Fig. 3A). Computerized image analysis showed that the average longest neurite and the total neurite outgrowth $(\mu \mathrm{m})$ were significantly higher in neurons treated with stimulated ASC CM compared with ASC CM (Fig. 3B, C).

Angiogenesis was assessed by measuring the formation of capillary tube-like formations of endothelial cells (HUVEC) on a nutrient-rich extracellular matrix gel (Fig. 4). HUVEC seeded in stem cell growth medium adopted an elongated phenotype within $4 \mathrm{~h}$ (Fig. 4A), which was in contrast to cells grown on tissue culture plastic that showed a characteristic "cobblestone" morphology (Fig. 4A). When the HUVEC were exposed to CM from ASC or stimulated ASC, there was a noticeable increase in the amount of elongation and the formation of more complex networks of cells (Fig. 4A). Quantification of the length of the tubes (by measuring the continuously linked end-to-end cell contacts) showed there was a significant $(P<0.05)$ increase from $1,696 \pm 192.30 \mu \mathrm{m}$ in control cultures to $2,346 \pm 186.30 \mu \mathrm{m}$ in HUVEC exposed to ASC medium and a further increase to $3,667 \pm 172.50 \mu \mathrm{m}$ in the presence of stimulated cells CM (Fig. 4B). HUVEC 

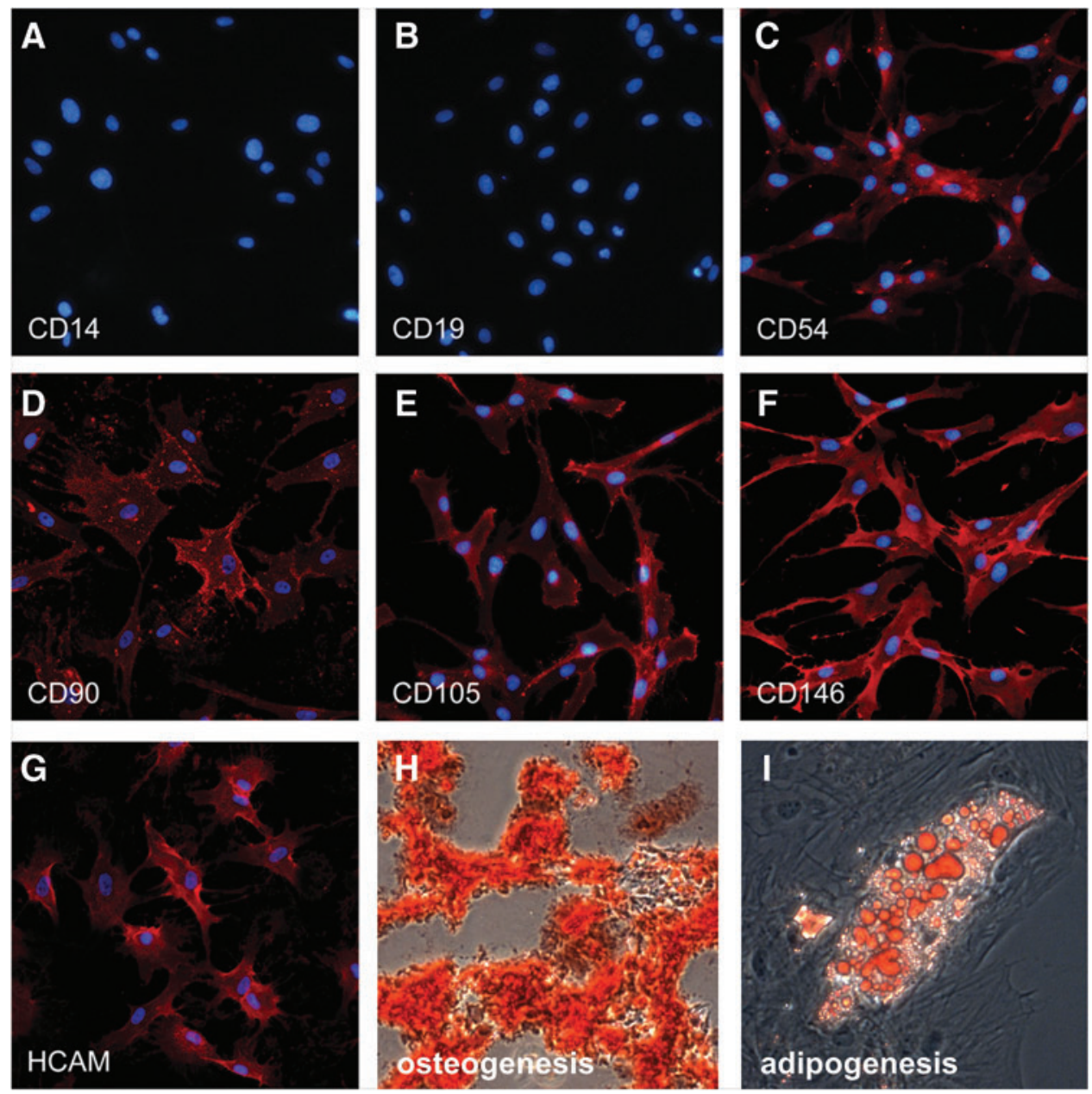

FIG. 1. Human stem cell characterization. Adiposederived stem cells (ASCs) immunostained at passage 2 were negative for the hematopoietic cell markers CD14 (A) and CD19 (B) and positive (red staining AlexaFluor568) for mesenchymal stem cell markers CD54 (C), CD90 (D), CD105 (E), CD146 (F) and HCAM (G). Blue staining in $(\mathbf{A}-\mathbf{G})$ is DAPI for labeling of cell nuclei. After differentiation along osteogenic and adipogenic lineages, cells were respectively positive for Alizarin red $\mathbf{( H )}$ and Oil Red $\mathrm{O}$ (I). Color images available online at www.liebertpub.com/scd

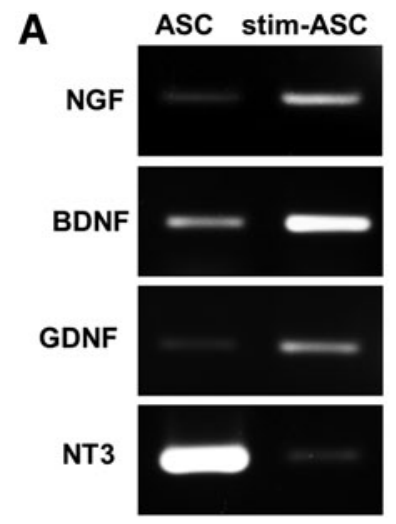

C

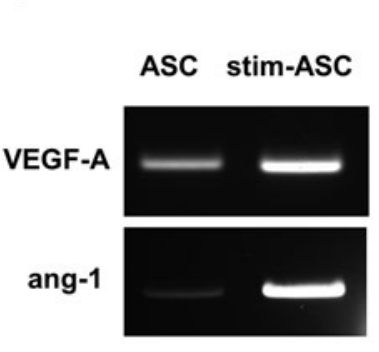

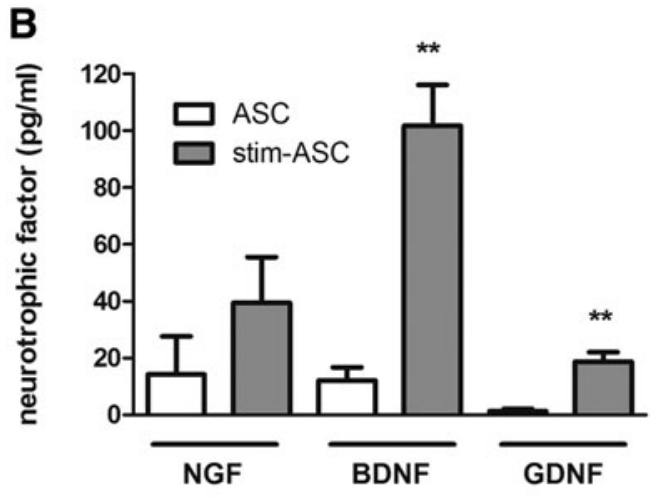

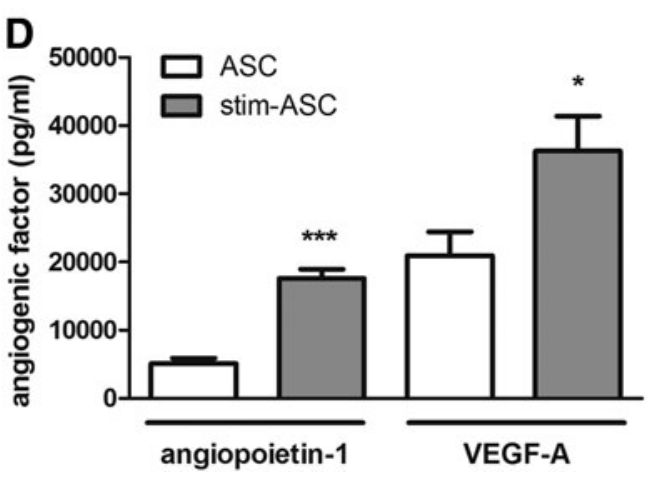

FIG. 2. Stimulation of ASC enhances neurotrophic and angiogenic factor gene expression and protein secretion. (A) RT-PCR showed that nerve growth factor (NGF), brain-derived neurotrophic factor (BDNF), and glial cell-derived neurotrophic factor (GDNF) genes were up-regulated in stimulated ASC (stim-ASC), whereas neurotrophin 3 (NT3) was down-regulated. (B) ELISA analysis of stimulated cell (stim-ASC) supernatants showed significantly elevated levels of BDNF and GDNF protein compared with unstimulated ASC (ASC). (C) The angiogenic factors vascular endothelial growth factor-A (VEGF-A) and angiopoietin-1 (ang1) genes were also up-regulated in the stimASC compared with control ASC, and this was consistent with elevated secretion levels detected by ELISA (D). ${ }^{*} P<0.05 ;{ }^{* *} P<0.01$; ${ }^{* * *} P<0.001$ significantly different in stimulated ASC compared with respective control ASC. $n=6$ independent experiments. 
FIG. 3. ASC stimulate neurite outgrowth of rat dorsal root ganglia (DRG) neurons. (A) $\beta$ III-tubulin immunostaining of DRG neurons exposed to control stem cell medium (control med), stimulation medium (stim med), $48 \mathrm{~h}$ ASC conditioned medium (CM) (ASC med), and $48 \mathrm{~h}$ stimulated ASC CM (stim-ASC med). Quantitative analysis of the mean longest neurite length (B) and total neurite outgrowth (C) for the four groups. ${ }_{* * *} P<0.001$ significantly higher neurite outgrowth compared with respective medium-only controls. Connecting lines; ${ }^{* *} P<0.01$ and *** $P<0.001$ show significantly higher neurite outgrowth with stimulated ASC CM compared with control ASC CM. $n=6$ independent experiments.

\section{A}
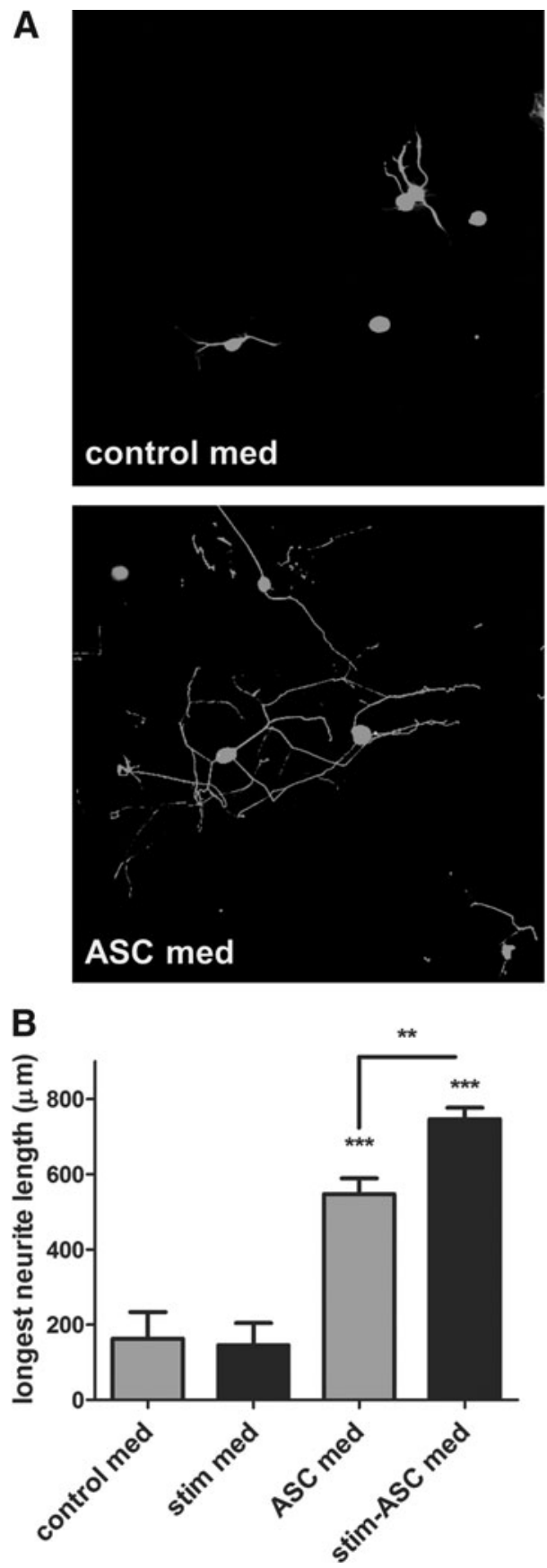

\section{stim med}
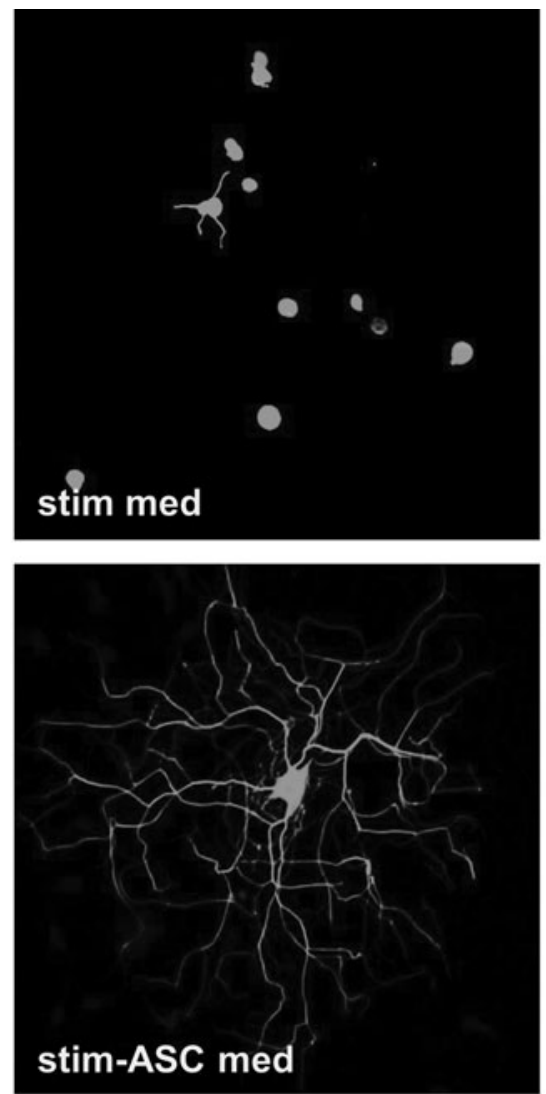

stim-ASC med

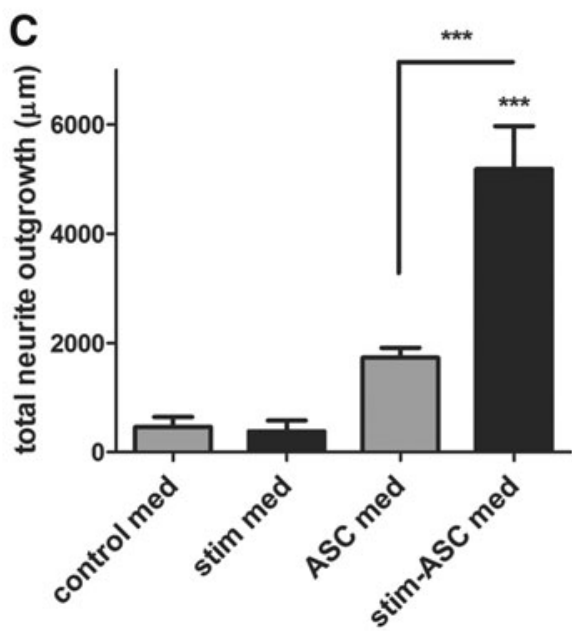

cultured in medium from both types of stem cells also showed significant increases in the number of closed networks formed when compared with control medium alone (Fig. 4C). The potentiaton of the angiogenic response in the presence of stimulated-ASC medium was not attributable to the stimulation factors alone, as medium was collected from the cells after these molecules had been washed out (see Materials and Methods section).

\section{Rat sciatic nerve injury}

A $10 \mathrm{~mm}$ rat sciatic nerve injury model was used to assess the in vivo effects of the cells. Fibrin conduits were seeded with $2 \times 10^{6}$ cells, and nerve regeneration and angiogenesis were measured 2 weeks after transplantation. $\beta$ III-tubulin immunofluorescence was used to stain axons (Fig. 5A). The counts of regenerating axons between the proximal stump and regenerating front were significantly higher $(P<0.05)$ in the stimulated-ASC group compared with rats treated with the conduit filled with matrix alone and devoid of cells (Fig. 5B). There was also a significant increase in the distance of the furthest regenerating axons in both stem cell-seeded groups (Fig. 5C). There was no significant difference between these two cell groups. Staining with a human nuclear antigen-specific antibody showed the ASC were still present in the conduit at 2 weeks (Fig. 5D).

qRT-PCR analysis of the sensory L4-L6 DRG neurons and corresponding motor neuron containing spinal cord 
A
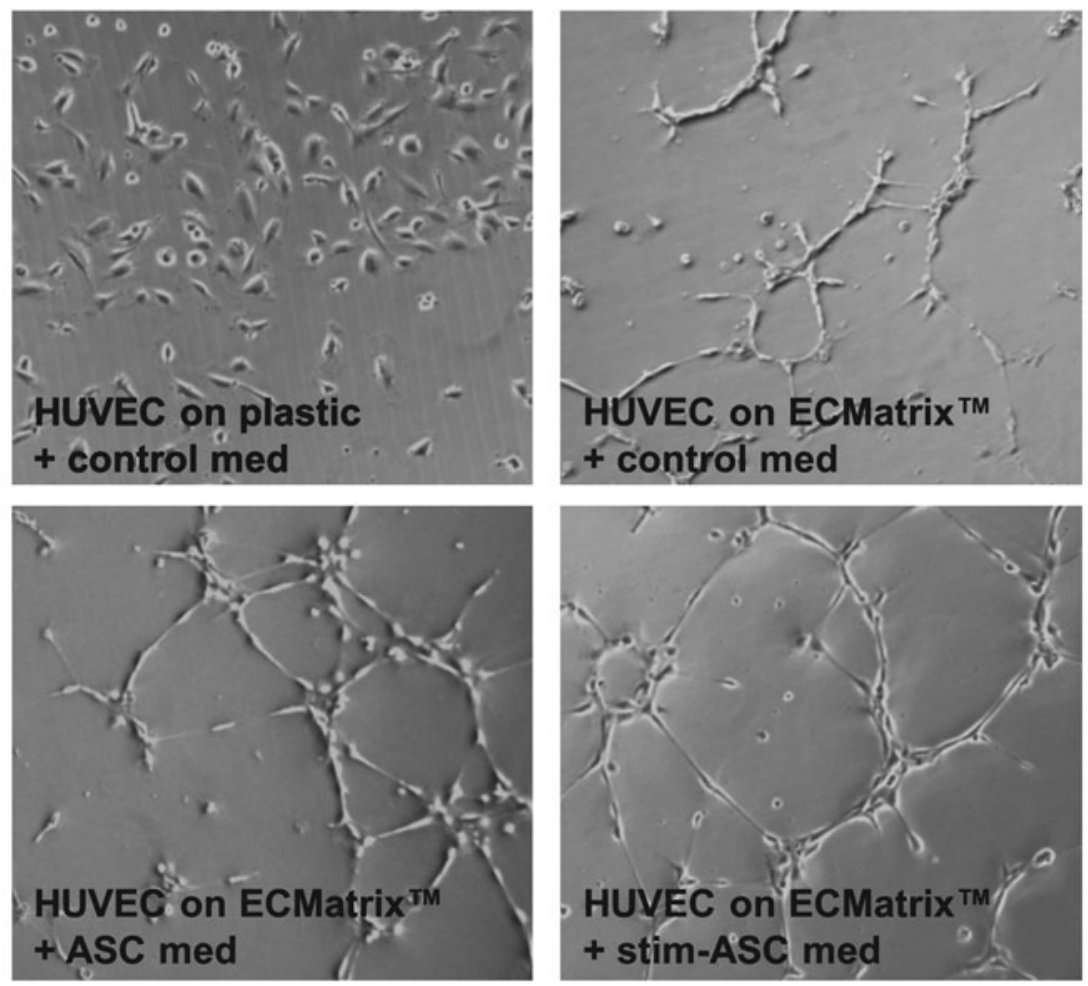

B

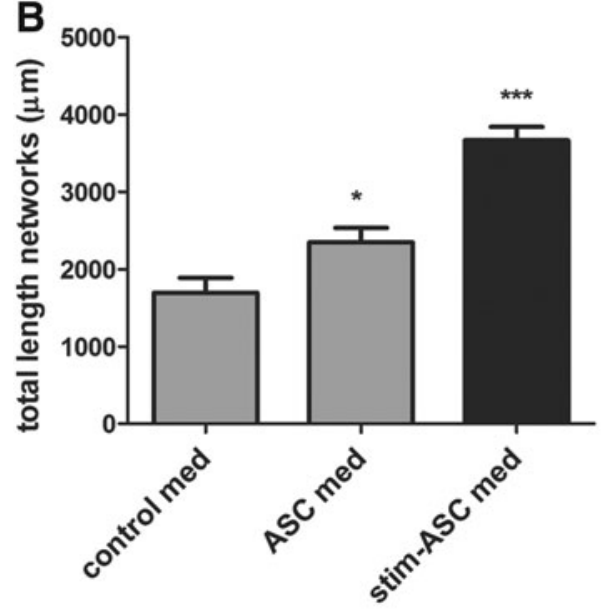

C

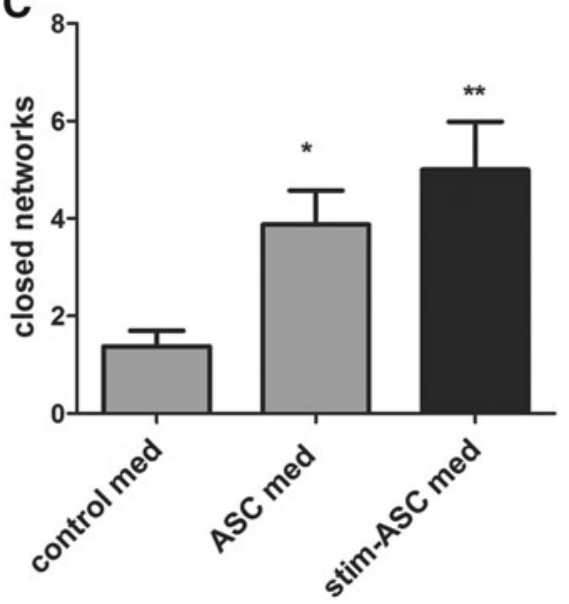

FIG. 4. ASC stimulate in vitro angiogenesis. (A) Human umbilical vein endothelial cells (HUVEC) were seeded onto either tissue culture plastic or ECMatrix ${ }^{\mathrm{TM}}$, which stimulates the cells to form capillary tube-like structures (top row). HUVEC seeded on ECMatrix in the presence of ASC-conditioned medium $(\mathrm{CM})$ or stimulated ASC CM resulted in greater cell elongation and more extensive cell networks (bottom row). Quantitative analysis of the total length of networks (B) and the number of closed networks (C) for HUVEC seeded on ECMatrix in stem cell growth medium (control med), ASC CM (ASC med) or stimulated ASC CM (stim-ASC med). $\quad{ }^{*} P<0.05, \quad{ }^{*} P<0.01$, and ${ }_{* * *} P<0.001$ significantly different from control med. $n=4$ independent experiments. segments revealed that a number of regeneration- and apoptosis-related genes were differentially modulated after the nerve repair (Fig. 6). Compared with control uninjured animals, the rats treated with the fibrin conduits without cells showed an approximately fourfold increase in GAP-43 expression levels in the DRG and spinal cord. Addition of stem cells to the nerve conduits had no further effect on GAP-43 expression in the DRG but significantly increased the expression levels in the spinal cord (Fig. 6A). There was a $3.50 \pm 0.26$-fold increase in caspase- 3 expression levels in the DRG of nerve-injured animals treated with conduits without cells compared with control rats (Fig. 6B). DRG caspase-3 levels were significantly $(P<0.01)$ reduced when the conduits were filled with stimulated cells, while unstimulated ASC had no significant effect (Fig. 6B). There were no significant differences in caspase- 3 expression levels in the spinal cord of all four groups (Fig. 6B). Compared with control uninjured ani- mals, activating transcription factor 3 (ATF-3) expression levels were significantly $(P<0.001)$ increased in both the DRG and spinal cords of rats with nerve injury repaired with conduit alone (Fig. 6C). Addition of either cell type to the conduits further significantly increased the expression of ATF3 in the spinal cords, but there was no effect on levels in the DRG (Fig. 6C). The binding partner of ATF-3, c-jun, was significantly increased 3.68 \pm 0.44 -fold above control levels in the DRG of nerve-injured animals treated with conduits without cells (Fig. 6D). These levels were significantly $(P<0.05)$ reduced in the animals treated with nerve conduits containing either type of stem cell (Fig. 6D). Animals with nerve injury and repair in all three groups showed significantly $(P<0.001)$ reduced c-jun expression levels in the spinal cords compared with control rats (Fig. 6D).

Angiogenesis within the nerve conduits was determined using immunofluorescence staining with rat endothelial cell 
FIG. 5. ASC enhance nerve regeneration in vivo. (A) $\beta$ III-tubulin staining of a longitudinal section through the nerve conduit showing regeneration from the proximal stump. Outline of the conduit is shown by the fine dashed line. The number of axon profiles were counted at $500 \mu \mathrm{m}$ intervals starting at $2 \mathrm{~mm}$ from the proximal stump (B) and using an optical micro-grid; the distance of the furthest regenerating axon was also measured in control conduits (no cells), conduits seeded with ASC (ASC), and conduits seeded with stimulated ASC (stim-ASC) (C). ${ }^{*} P<0.05$ significantly different from conduits without cells. $n=6 / 7$ animals per group. (D) The presence of human nuclei-specific antigen (h-nuclei; green) showed that cells survived in the conduit, but there were low levels of co-localization with $\mathrm{S} 100$ antigen (red), indicating that the transplanted cells did not differentiate to a Schwann cell phenotype in large numbers. Color images available online at www.liebertpub .com/scd
A
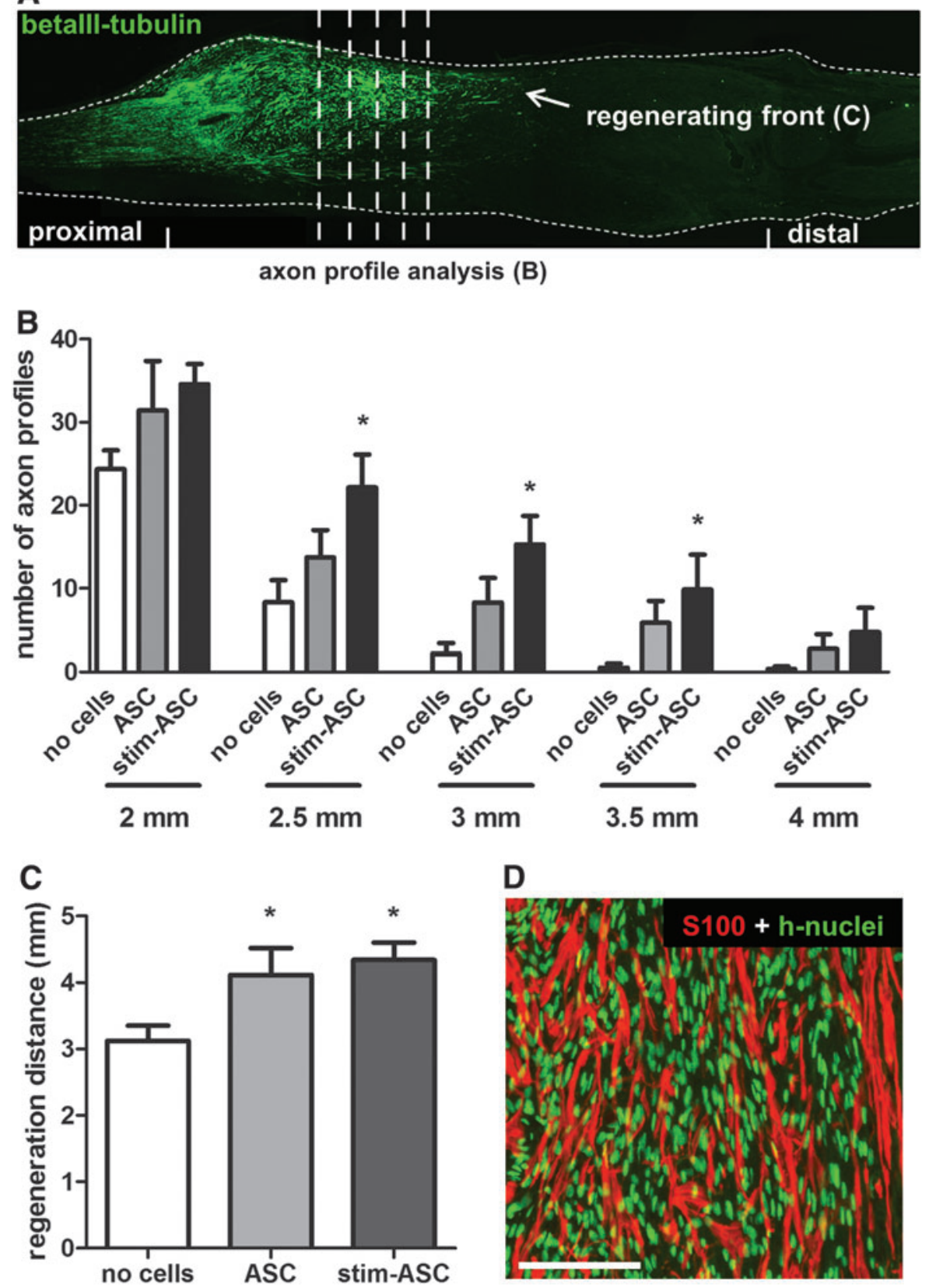

antigen (RECA-1) antibody (Fig. 7A). At the mid-point of the conduits containing fibrin matrix alone (no cells), there were a few RECA-1-positive cells, but in the conduits containing ASC and stimulated ASC, there was a marked increase in reactivity. Quantification of the number of RECA-1-positive cells showed a siginificant increase from $9.70 \pm 5.63 / \mathrm{mm}^{2}$ in conduits without cells to $26.49 \pm 3.66 / \mathrm{mm}^{2}(P<0.05)$ in ASCseeded conduits and $34.55 \pm 4.86 / \mathrm{mm}^{2}(P<0.01)$ in stimulated ASC-loaded conduits (Fig. 7B).

\section{Discussion}

In this study, we have shown that using an in vitro protocol to stimulate ASCs leads to enhanced expression of a number of neurotrophic and angiogenic molecules. Further- more, the stimulated cells boost axon regeneration and angiogenesis when transplanted within a nerve conduit. This suggests that the easily accessible, abundant supply of stem cells harvested from adipose tissue could potentially be used for peripheral nerve repair.

Stimulation of the ASCs resulted in increased NGF, BDNF, and GDNF gene expression and consequent enhanced levels of these secreted proteins. The stimulating mixture contained forskolin, bFGF, PDGF-AA, and neuregulin-1 and these factors may act alone or together to control the signaling pathways mediating the expression of these neurotrophic factors. For instance, forskolin increases NGF mRNA levels in Schwann cells [32], while bFGF enhances BDNF expression in retinal ganglion cells [33]. Previously, we showed that the same mixture of factors could induce the expression of 
A

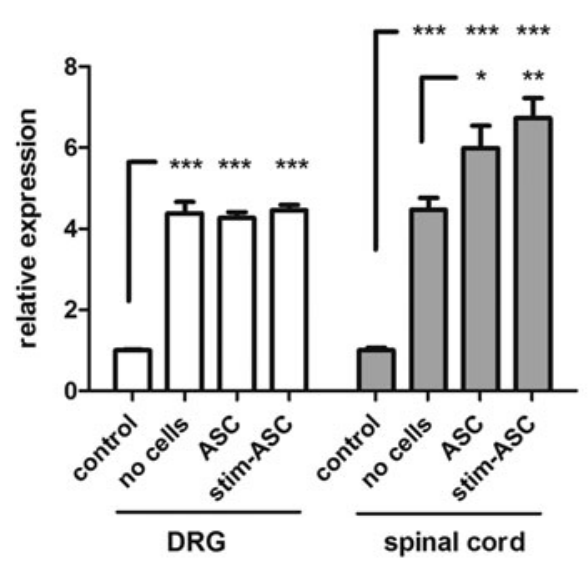

C

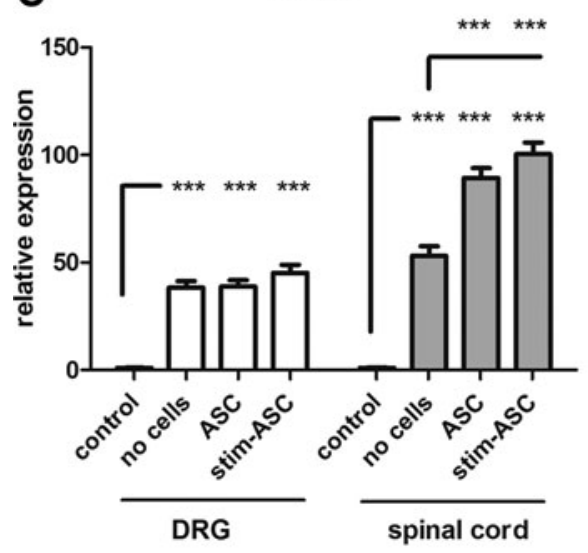

B caspase-3

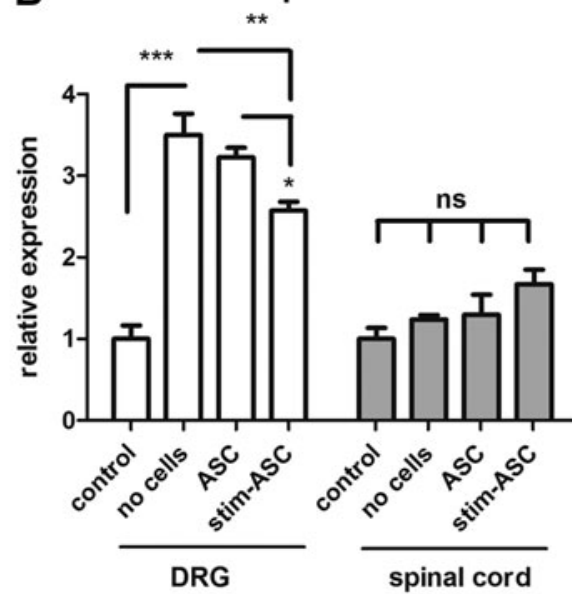

D

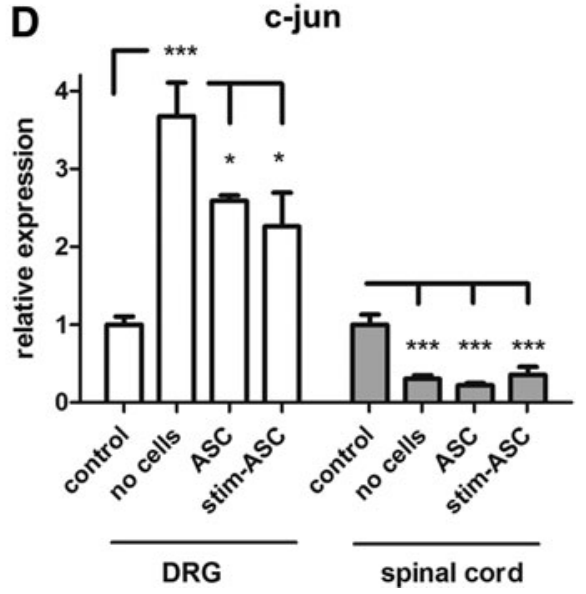

FIG. 6. Quantitative RT-PCR of nerve tissue 2 weeks after injury and repair. (A) GAP-43 (B) caspase3 (C) activating transcription factor 3 (ATF-3), and (D) c-jun expression levels were measured in L4-L6 DRG and spinal cord segments taken from uninjured rats (control) and rats with nerve injury treated with conduits without cells (no cells) or conduits seeded with ASC (ASC) or stimulated ASC (stim-ASC). Relative expression levels are shown with regard to control samples (value $=1$ ). Connecting lines show relative significance; ${ }^{*} P<0.05$, ${ }^{* *} P<0.01$, and ${ }^{* * *} P<0.001$, n.s., not significantly different. $n=5$ from pooled animal RNA samples $(6 / 7$ per group). glial cell proteins in rat ASC [15]. Varying levels of S100 mRNA were observed in the stimulated human stem cells, but we did not detect S100 protein (data not shown). GFAP mRNA and protein were also undetectable (data not shown), which is in contrast to Tomita et al. [34]. The elevated secretion of neurotrophic factors was consistent with increased neurite outgrowth of DRG neurons exposed to CM from the stem cells. Three major cell types are found in the adult rat DRG: heavy chain neurofilament positive neurons, which respond to NGF and BDNF; peptidergic small-diameter neurons that respond to NGF; and third, IB4-binding neurons, which respond to GDNF through the RET receptor tyrosine kinase [35]. We have previously reported that human bone marrow stem cells also enhance DRG neurite outgrowth but most likely independently of BDNF [36]. Other studies have shown that human ASC express a range of neurotrophic factors which can enhance neurite outgrowth of neuronal cell lines $[23,34,37]$. Thus, the precise mechanism of stimulated ASC-mediated neurite outgrowth in our system remains to be elucidated.

Stimulation of ASC also enhanced the expression of the angiogenic molecules, VEGF-A, and angiopoietin-1. Numerous studies have indicated that VEGF plays a pivotal role in ASC-mediated regeneration [38]. When ASC are cultured under hypoxic conditions, they secrete increased levels of VEGF and can convert to an endothelial cell phenotype
$[39,40]$. ASC are often genetically modified to over-express VEGF [41,42], but we observed significant VEGF secretion levels in control cultures of ASC that could be further potentiated by treatment with stimulating factors. Paracrine release from VEGF-engineered ASC was shown to promote endothelial cell survival and tube formation in vitro [41]. We found that unstimulated ASC could promote HUVEC capillary-like formation and that this was significantly enhanced by stimulating the stem cells. In contrast, the results of Strassburg et al. showed that ASC CM had no effect on HUVEC but rather, direct cell contact of ASC with endothelial progenitors was necessary for in vitro angiogenesis [43]. The growth factors bFGF and PDGF used in our stimulation protocol are the most likely to control the production of VEGF, as there is significant cross-talk between all three molecules [44]. In addition to the secretion of VEGF, we found elevated levels of angiopoietin-1 in the stimulated ASC medium. We have previously shown that rat ASC express angiopoietin-1 [45], but there are a few studies about this molecule in human cells. Blasi et al. suggested that ASC can be distinguished from dermal fibroblasts by their increased angiogenic profile, which is partly attributable to the expression of angiopoietins [46]. In contrast, another study showed that it was necessary to genetically modify the ASC to enable significant secretion of angiopoietin [47]. In the context of our study, it is also interesting to note that 
A
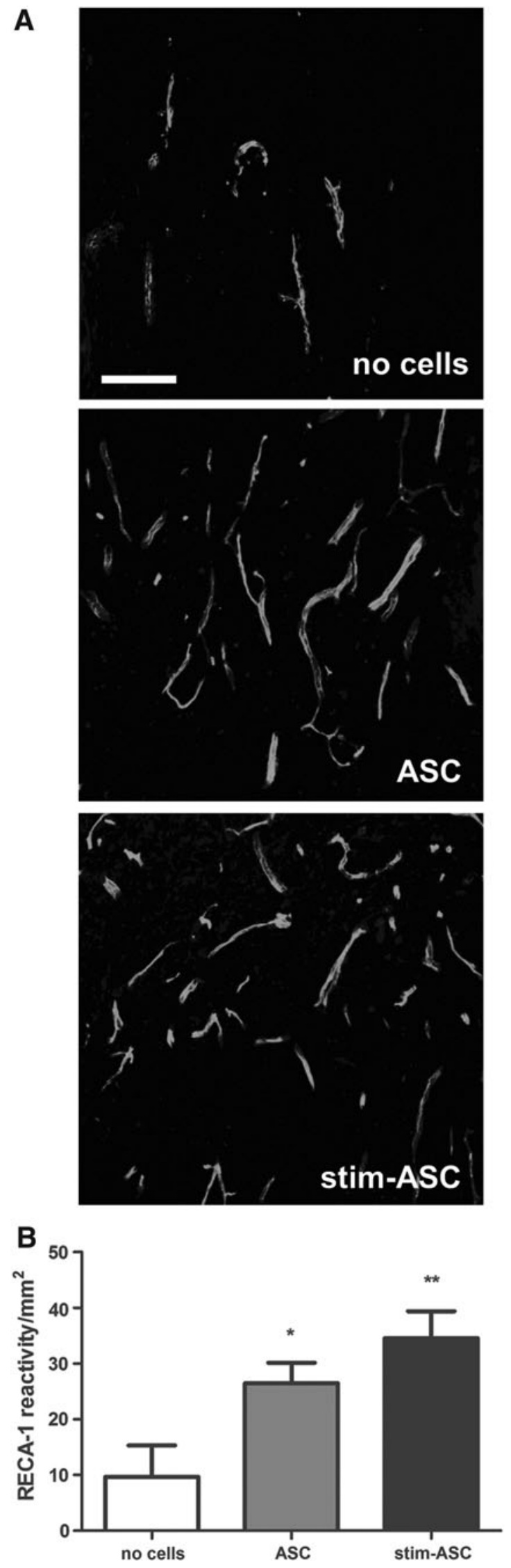

adipocyte-derived angiopoietin-1 supports neurite outgrowth and synaptogenesis of sensory neurons [48].

We studied the effect of stem cell transplantation in a rat $10 \mathrm{~mm}$ sciatic nerve gap injury model. Both control and stimulated ASC enhanced the distance of axon regeneration after 2 weeks, but the stimulated cells evoked more total outgrowth. The human nuclear antigen-positive transplanted cells were detected in high abundance throughout the nerve conduits, but only a few showed co-staining with S100 protein, suggesting against significant in vivo differentiation toward a Schwann cell phenotype. Since our first report of Schwann cell-like differentiation of rat ASC [15], a number of research groups have investigated the effect of rat ASC on peripheral nerve regeneration. We showed that Schwann cell-like differentiated ASC could enhance motor neuron regeneration and improve evoked electrical potentials in the gastrocnemius muscle [26] and also at early stages of regeneration, we observed a down-regulation of apoptotic markers in the DRG which was suggestive of a pro-survival effect [29]. Undifferentiated rat ASC have also been shown to enhance peripheral nerve repair $[28,30]$, and they may act synergistically with Schwann cells to secrete growth factors such as NGF [25]. Alternatively, the stem cells can be neurally induced to release enhanced levels of BDNF, which is necessary for their nerve stimulatory effects [27]. This may also account for our improved results using stimulated human ASC.

There are significantly fewer reports using human ASC in animal peripheral nerve injury models. Marconi et al. reported that human ASC systemically injected into a mouse model of sciatic crush could accelerate functional recovery, and this might be attributed to a reduced inflammatory reaction and ASC interaction with endogenous Schwann cells to produce enhanced levels of GDNF [49]. Adipose precursor cells transplanted in polycaprolactone conduits were shown to reduce muscle atrophy in a rat short nerve gap defect model, but the improvements in the sciatic functional index were temporary [50]. Furthermore, in that study, there was no evidence of stem cell trans-differentiation in vivo [50], which is in contrast to the recent report by Tomita et al. [34] in which the authors had first stimulated the cells using the same protocol as described in our study. Repetitive stimulation of ASC with neural differentiation medium can also boost the therapeutic effects human ASC in the rat sciatic nerve injury model [51].

The studies mentioned earlier reporting human ASC effects in vivo utilized the athymic animal model, whereas we treated our rats with the immunosuppressant, CsA. We found that CsA was required for human cell survival, as previously reported, when using human bone marrow stem cells in the rat model [31]. Nevertheless, in a non-xenogenic setting, human ASC could act as effective suppressors of

FIG. 7. ASC enhance the vascularity of nerve conduits. (A) Sections at the mid-point of the nerve conduit stained with anti-RECA-1 antibody show enhanced vascularity of conduits containing ASC or stimulated ASC (stim-ASC) when compared with conduits devoid of cells (no cells). (B) Quantitative analysis of RECA-1 staining showed significantly elevated levels in conduits containing ASC $\left({ }^{*} P<0.05\right)$ and stimulated ASC $\left({ }^{*} P<0.01\right) . n=6 / 7$ animals per group. 
T-cell proliferation [52] and B-cell function [53] and thereby modulate the inflammatory reaction after peripheral nerve injury. Interestingly, human ASC can also facilitate the immunosuppressive effects of CsA [54], so they could potentially be used to reduce the adverse effects of CsA, which is a requirement for effective nerve allografting.

The studies using human ASC have not elucidated the potential mechanisms by which the stem cells could directly act on the nervous system to enhance regeneration. We, therefore, examined the effect of stem cell transplantation on the expression of a number of genes known to be affected by peripheral nerve injury. Growth-associated protein GAP-43 is a molecule that is up-regulated in sciatic motor neurons and L4-L6 DRG neurons after sciatic nerve injury [55] and has been implicated as one of the several important mediators of peripheral nerve regeneration [6]. Typically, treatments such as electrical stimulation and growth factor administration, which stimulate regeneration, are associated with elevated levels of GAP-43 [56,57]. We found that nerve repair which was performed with either ASC or stimulated ASC increased the expression levels of GAP-43 in the spinal cord but not in the DRG. This suggests that the stem cells might enhance motor neuron regeneration to a greater extent than sensory neurons. A number of studies have shown that peripheral nerve axotomy leads to DRG sensory neuron cell death $[58,59]$. In this study, we found that using stimulated human ASC, we were able to reduce the expression levels of caspase-3, an important mediator of apoptosis, suggesting that cell transplantation could provide a neuroprotective effect in addition to boosting regeneration. This is consistent with our previous study using rat ASC [29] and another report using a mouse model [60]. Regeneration and apoptosis-associated genes are controlled by multiple signaling pathways and in this study, we examined the expression levels of ATF-3 and c-jun. ATF-3 is rapidly induced in DRG sensory neurons and motor neurons after axotomy [61]. ATF-3 increases the intrinsic growth state of DRG neurons to enhance peripheral nerve regeneration [62] and in the central nervous system, regenerating neurons are associated with increased ATF-3 expression [63]. Stem cell transplantation increased ATF-3 expression in the spinal cord but not in DRGs, which is consistent with the GAP-43 regeneration gene expression profile. Interestingly, transgenic mice constitutively expressing ATF-3 do not show enhanced levels of GAP-43 [62], but GAP-43 expression levels are higher in ATF3-positive neurons after electrical stimulation [56]. In the DRG, it has been shown that non-regenerating neurons fail to up-regulate ATF-3 [64]. In our experiments, it is possible that the stem cells boosted the number of regenerating motor neurons via enhanced expression of ATF-3.

ATF-3 can physically interact with another transcription factor, c-jun, to modulate the nervous system response to axotomy [65]. c-jun is one of the earliest molecules that are up-regulated after nerve injury, and it has been shown to regulate diverse responses underlying degeneration, survival, and regeneration [66]. This apparent dichotomy of function is highlighted by studies of c-jun-deficient mice which show that lack of c-jun prevents neuronal cell death after facial nerve axotomy but impairs regeneration and reinnervation of targets [67]. Further studies in which neuron specific c-jun was deleted showed similar effects [68]. We found, consistent with previous reports [69], that c-jun was up-regulated in the injured DRG and when we transplanted stem cells, these levels were reduced. Thus, stem cells might exert a neuroprotective role (consistent with reduced caspase-3 levels) via release of molecules that act on c-jun. For instance, NGF that was up-regulated by our stimulation protocol has been shown to reduce injury-induced increases in c-jun immunoreactivity [70]. Conversely, inhibition of cjun phosphorylation has been shown to reduce axonal outgrowth of DRG neurons [71]. Similar anomalies have been reported when studying c-jun expression in the motor neurons. Increased levels of phosphorylated c-jun are observed in distally axotomized motor neurons of neonatal rats, but this is not the case for adult rats [72]. However, avulsion injury in adult rats results in increased phospho c-jun, which is associated with significant cell death [72]. A long-term association of phosphorylated c-jun with ATF-3 in axotomized motor neurons correlates with degenerating neurons [73]. In other studies, decreased c-jun expression has been correlated with impaired motor neuron regeneration in aged animals [74]. We found that nerve injury alone downregulated c-jun levels in the spinal cord, and we, therefore, propose that this might protect motor neurons against axotomy-induced cell death. Nevertheless, how decreased c-jun levels can be correlated with our other observations of increased GAP-43 expression and improved regeneration in the periphery remains to be elucidated. It should be noted that we have examined these molecules at just one time point and the interaction between the various transcription factors and regeneration-associated genes is likely to be a very dynamic process after injury.

In addition to acting directly on the nervous system, we have also shown that the stem cell transplantation can boost vascularization at the area of nerve injury. Many studies have demonstrated that vascularized nerve grafts are superior to non-vascularized nerve grafts with regard to healing. For example, the addition of VEGF to silicone conduits improves nerve regeneration [75] and nerve conduits that facilitate early vascularization are superior to simple silicone conduits [76]. Our results showing an increased amount of RECA-1-positive staining in conduits supplemented with stem cells could be attributed to the high levels of VEGF and angiopoietin secreted by the stem cells. Other very recent studies have indicated that human ASC used in animal experimental models can promote tissue formation and enhance graft retention as a result of enhanced vascularity $[77,78]$.

In conclusion, our study shows that human ASCs are a rich source of neurotrophic and angiogenic factors. The cells can promote axon regeneration by directly interacting with intrinsic regeneration mechanisms and also by contributing to local repair via enhanced vascularization. Growth factorstimulated cells were typically the most effective, but longerterm studies will be required to determine whether these cells afford significantly better functional outcomes.

\section{Acknowledgments}

The authors would like to thank Gunnel Folkesson and Gunvor Hellström for their excellent technical assistance. This study was supported by the Swedish Research Council, European Union, Umeå University, County of Västerbotten, Åke Wibergs Stiftelse, and the Clas Groschinskys Minnesfond. 


\section{Author Disclosure Statement}

There are no conflicts of interest.

\section{References}

1. Isaacs J. (2010). Treatment of acute peripheral nerve injuries: current concepts. J Hand Surg Am 35:491-497.

2. Wiberg M and G Terenghi. (2003). Will it be possible to produce peripheral nerves? Surg Technol Int 11:303-310.

3. Bell JH and JW Haycock. (2012). Next generation nerve guides: materials, fabrication, growth factors, and cell delivery. Tissue Eng Part B Rev 18:116-128.

4. Daly W, L Yao, D Zeugolis, A Windebank and A Pandit. (2012). A biomaterials approach to peripheral nerve regeneration: bridging the peripheral nerve gap and enhancing functional recovery. J R Soc Interface 9:202-221.

5. Nectow AR, KG Marra and DL Kaplan. (2011). Biomaterials for the development of peripheral nerve guidance conduits. Tissue Eng Part B Rev 18:40-50.

6. Ide C. (1996). Peripheral nerve regeneration. Neurosci Res 25:101-121.

7. Dadon-Nachum M, E Melamed and D Offen. (2011). Stem cells treatment for sciatic nerve injury. Expert Opin Biol Ther 11:1591-1597.

8. Erba P, G Terenghi and PJ Kingham. (2010). Neural differentiation and therapeutic potential of adipose tissue derived stem cells. Curr Stem Cell Res Ther 5:153-160.

9. Zuk PA. (2010). The adipose-derived stem cell: looking back and looking ahead. Mol Biol Cell 21:1783-1787.

10. Strem BM, KC Hicok, M Zhu, I Wulur, Z Alfonso, RE Schreiber, JK Fraser and MH Hedrick. (2005). Multipotential differentiation of adipose tissue-derived stem cells. Keio J Med 54:132-141.

11. Witkowska-Zimny M and K Walenko. (2011). Stem cells from adipose tissue. Cell Mol Biol Lett 16:236-257.

12. di Summa PG, DF Kalbermatten, W Raffoul, G Terenghi and PJ Kingham. (2013). Extracellular matrix molecules enhance the neurotrophic effect of Schwann cell-like differentiated adipose-derived stem cells and increase cell survival under stress conditions. Tissue Eng Part A 19:368-379.

13. Jiang L, JK Zhu, XL Liu, P Xiang, J Hu and WH Yu. (2008). Differentiation of rat adipose tissue-derived stem cells into Schwann-like cells in vitro. Neuroreport 19:1015-1019.

14. Kaewkhaw R, AM Scutt and JW Haycock. (2011). Anatomical site influences the differentiation of adipose-derived stem cells for Schwann-cell phenotype and function. Glia 59:734-749.

15. Kingham PJ, DF Kalbermatten, D Mahay, SJ Armstrong, M Wiberg and G Terenghi. (2007). Adipose-derived stem cells differentiate into a Schwann cell phenotype and promote neurite outgrowth in vitro. Exp Neurol 207:267-274.

16. Wei Y, K Gong, Z Zheng, L Liu, A Wang, L Zhang, Q Ao, Y Gong and X Zhang. (2010). Schwann-like cell differentiation of rat adipose-derived stem cells by indirect co-culture with Schwann cells in vitro. Cell Prolif 43:606-616.

17. Mantovani C, D Mahay, M Kingham, G Terenghi, SG Shawcross and M Wiberg. (2010). Bone marrow- and adipose-derived stem cells show expression of myelin mRNAs and proteins. Regen Med 5:403-410.

18. Xu Y, L Liu, Y Li, C Zhou, F Xiong, Z Liu, R Gu, X Hou and C Zhang. (2008). Myelin-forming ability of Schwann cell-like cells induced from rat adipose-derived stem cells in vitro. Brain Res 1239:49-55.
19. Kapur SK and AJ Katz. (2013). Review of the adipose derived stem cell secretome. Biochimie [Epub ahead of print]; DOI: 10.1016/j.biochi.2013.06.001.

20. Salgado AJ, RL Reis, NJ Sousa and JM Gimble. (2010). Adipose tissue derived stem cells secretome: soluble factors and their roles in regenerative medicine. Curr Stem Cell Res Ther 5:103-110.

21. Chung JY, W Kim, W Im, DY Yoo, JH Choi, IK Hwang, MH Won, IB Chang, BM Cho, HS Hwang and SM Moon. (2012). Neuroprotective effects of adipose-derived stem cells against ischemic neuronal damage in the rabbit spinal cord. J Neurol Sci 317:40-46.

22. Kalbermatten DF, D Schaakxs, PJ Kingham and M Wiberg. (2011). Neurotrophic activity of human adipose stem cells isolated from deep and superficial layers of abdominal fat. Cell Tissue Res 344:251-260.

23. Lattanzi W, MC Geloso, N Saulnier, S Giannetti, MA Puglisi, V Corvino, A Gasbarrini and F Michetti. (2011). Neurotrophic features of human adipose tissue-derived stromal cells: in vitro and in vivo studies. J Biomed Biotechnol 2011:468705.

24. Wei X, L Zhao, J Zhong, H Gu, D Feng, BH Johnstone, KL March, MR Farlow and Y Du. (2009). Adipose stromal cellssecreted neuroprotective media against neuronal apoptosis. Neurosci Lett 462:76-79.

25. Dai LG, GS Huang and SH Hsu. (2013). Sciatic nerve regeneration by co-cultured Schwann cells and stem cells on microporous nerve conduits. Cell Transplant 22:2029-2039.

26. di Summa PG, DF Kalbermatten, E Pralong, W Raffoul, PJ Kingham and G Terenghi. (2011). Long-term in vivo regeneration of peripheral nerves through bioengineered nerve grafts. Neuroscience 181:278-291.

27. Lopatina T, N Kalinina, M Karagyaur, D Stambolsky, K Rubina, A Revischin, G Pavlova, Y Parfyonova and V Tkachuk. (2011). Adipose-derived stem cells stimulate regeneration of peripheral nerves: BDNF secreted by these cells promotes nerve healing and axon growth de novo. PLoS One 6:e17899.

28. Mohammadi R, S Azizi, N Delirezh, R Hobbenaghi and $K$ Amini. (2011). Comparison of beneficial effects of undifferentiated cultured bone marrow stromal cells and omental adipose-derived nucleated cell fractions on sciatic nerve regeneration. Muscle Nerve 43:157-163.

29. Reid AJ, M Sun, M Wiberg, S Downes, G Terenghi and PJ Kingham. (2011). Nerve repair with adipose-derived stem cells protects dorsal root ganglia neurons from apoptosis. Neuroscience 199:515-522.

30. Shen CC, YC Yang and BS Liu. (2012). Peripheral nerve repair of transplanted undifferentiated adipose tissue-derived stem cells in a biodegradable reinforced nerve conduit. J Biomed Mater Res A 100:48-63.

31. McGrath AM, M Brohlin, PJ Kingham, LN Novikov, M Wiberg and LN Novikova. (2012). Fibrin conduit supplemented with human mesenchymal stem cells and immunosuppressive treatment enhances regeneration after peripheral nerve injury. Neurosci Lett 516:171-176.

32. Yamamoto M, G Sobue, M Li, Y Arakawa, T Mitsuma and $\mathrm{K}$ Kimata. (1993). Nerve growth factor (NGF), brain-derived neurotrophic factor (BDNF) and low-affinity nerve growth factor receptor (LNGFR) mRNA levels in cultured rat Schwann cells; differential time- and dose-dependent regulation by cAMP. Neurosci Lett 152:37-40.

33. Soto I, JJ Rosenthal, JM Blagburn and RE Blanco. (2006). Fibroblast growth factor 2 applied to the optic nerve after axotomy up-regulates BDNF and TrkB in ganglion cells by 
activating the ERK and PKA signaling pathways. J Neurochem 96:82-96.

34. Tomita K, T Madura, Y Sakai, K Yano, G Terenghi and K Hosokawa. (2013). Glial differentiation of human adiposederived stem cells: implications for cell-based transplantation therapy. Neuroscience 236:55-65.

35. Priestley JV, GJ Michael, S Averill, M Liu and N Willmott. (2002). Regulation of nociceptive neurons by nerve growth factor and glial cell line derived neurotrophic factor. Can J Physiol Pharmacol 80:495-505.

36. Brohlin M, PJ Kingham, LN Novikova, LN Novikov and M Wiberg. (2012). Aging effect on neurotrophic activity of human mesenchymal stem cells. PLoS One 7:e45052.

37. Moriyama M, H Moriyama, A Ueda, Y Nishibata, H Okura, A Ichinose, A Matsuyama and T Hayakawa. (2012). Human adipose tissue-derived multilineage progenitor cells exposed to oxidative stress induce neurite outgrowth in PC12 cells through p38 MAPK signaling. BMC Cell Biol 13:21.

38. Song SY, HM Chung and JH Sung. (2010). The pivotal role of VEGF in adipose-derived-stem-cell-mediated regeneration. Expert Opin Biol Ther 10:1529-1537.

39. Rehman J, D Traktuev, J Li, S Merfeld-Clauss, CJ TemmGrove, JE Bovenkerk, CL Pell, BH Johnstone, RV Considine and KL March. (2004). Secretion of angiogenic and antiapoptotic factors by human adipose stromal cells. Circulation 109:1292-1298.

40. Thangarajah H, IN Vial, E Chang, S El-Ftesi, M Januszyk, EI Chang, J Paterno, E Neofytou, MT Longaker and GC Gurtner. (2009). IFATS collection: adipose stromal cells adopt a proangiogenic phenotype under the influence of hypoxia. Stem Cells 27:266-274.

41. Deveza L, J Choi, G Imanbayev and F Yang. (2013). Paracrine release from nonviral engineered adipose-derived stem cells promotes endothelial cell survival and migration in vitro. Stem Cells Dev 22:483-491.

42. Helmrich U, A Marsano, L Melly, T Wolff, L Christ, M Heberer, A Scherberich, I Martin and A Banfi. (2012). Generation of human adult mesenchymal stromal/stem cells expressing defined xenogenic vascular endothelial growth factor levels by optimized transduction and flow cytometry purification. Tissue Eng Part C Methods 18:283-292.

43. Strassburg S, H Nienhueser, GB Stark, G Finkenzeller and N Torio-Padron. (2013). Human adipose-derived stem cells enhance the angiogenic potential of endothelial progenitor cells, but not of human umbilical vein endothelial cells. Tissue Eng Part A 19:166-174.

44. Gerwins P, E Skoldenberg and L Claesson-Welsh. (2000). Function of fibroblast growth factors and vascular endothelial growth factors and their receptors in angiogenesis. Crit Rev Oncol Hematol 34:185-194.

45. Tse KH, PJ Kingham, LN Novikov and M Wiberg. (2012). Adipose tissue and bone marrow-derived stem cells react similarly in an ischaemia-like microenvironment. J Tissue Eng Regen Med 6:473-485.

46. Blasi A, C Martino, L Balducci, M Saldarelli, A Soleti, SE Navone, L Canzi, S Cristini, G Invernici, EA Parati, and G Alessandri. (2011). Dermal fibroblasts display similar phenotypic and differentiation capacity to fat-derived mesenchymal stem cells, but differ in anti-inflammatory and angiogenic potential. Vasc Cell 3:5.

47. Paul A, M Nayan, AA Khan, D Shum-Tim and S Prakash. (2012). Angiopoietin-1-expressing adipose stem cells genetically modified with baculovirus nanocomplex: investigation in rat heart with acute infarction. Int J Nanomedicine 7:663-682.
48. Kosacka J, M Nowicki, J Kacza, J Borlak, J Engele and K Spanel-Borowski. (2006). Adipocyte-derived angiopoietin-1 supports neurite outgrowth and synaptogenesis of sensory neurons. J Neurosci Res 83:1160-1169.

49. Marconi S, G Castiglione, E Turano, G Bissolotti, S Angiari, A Farinazzo, G Constantin, G Bedogni, A Bedogni and B Bonetti. (2012). Human adipose-derived mesenchymal stem cells systemically injected promote peripheral nerve regeneration in the mouse model of sciatic crush. Tissue Eng Part A 18:1264-1272.

50. Santiago LY, J Clavijo-Alvarez, C Brayfield, JP Rubin and KG Marra. (2009). Delivery of adipose-derived precursor cells for peripheral nerve repair. Cell Transplant 18:145-158.

51. Scholz T, A Sumarto, A Krichevsky and GR Evans. (2011). Neuronal differentiation of human adipose tissue-derived stem cells for peripheral nerve regeneration in vivo. Arch Surg 146:666-674.

52. Yoo KH, IK Jang, MW Lee, HE Kim, MS Yang, Y Eom, JE Lee, YJ Kim, SK Yang, et al. (2009). Comparison of immunomodulatory properties of mesenchymal stem cells derived from adult human tissues. Cell Immunol 259:150-156.

53. Bochev I, G Elmadjian, D Kyurkchiev, L Tzvetanov, I Altankova, P Tivchev and S Kyurkchiev. (2008). Mesenchymal stem cells from human bone marrow or adipose tissue differently modulate mitogen-stimulated B-cell immunoglobulin production in vitro. Cell Biol Int 32:384-393.

54. Shi D, L Liao, B Zhang, R Liu, X Dou, J Li, X Zhu, L Yu, D Chen and RC Zhao. (2011). Human adipose tissue-derived mesenchymal stem cells facilitate the immunosuppressive effect of cyclosporin A on T lymphocytes through Jagged-1mediated inhibition of NF-kappaB signaling. Exp Hematol 39:214-224.

55. Chong MS, M Fitzgerald, J Winter, M Hu-Tsai, PC Emson, U Wiese and CJ Woolf. (1992). GAP-43 mRNA in rat spinal cord and dorsal root ganglia neurons: developmental changes and re-expression following peripheral nerve injury. Eur J Neurosci 4:883-895.

56. Geremia NM, T Gordon, TM Brushart, AA Al-Majed and VM Verge. (2007). Electrical stimulation promotes sensory neuron regeneration and growth-associated gene expression. Exp Neurol 205:347-359.

57. Gordon T. (2009). The role of neurotrophic factors in nerve regeneration. Neurosurg Focus 26:E3.

58. Hart AM, G Terenghi and M Wiberg. (2008). Neuronal death after peripheral nerve injury and experimental strategies for neuroprotection. Neurol Res 30:999-1011.

59. Terenghi G, A Hart and M Wiberg. (2011). The nerve injury and the dying neurons: diagnosis and prevention. J Hand Surg Eur Vol 36:730-734.

60. Frattini F, FR Lopes, FM Almeida, RF Rodrigues, LC Boldrini, MA Tomaz, AF Baptista, PA Melo and AM Martinez. (2012). Mesenchymal stem cells in a polycaprolactone conduit promote sciatic nerve regeneration and sensory neuron survival after nerve injury. Tissue Eng Part A 18:2030-2039.

61. Tsujino H, E Kondo, T Fukuoka, Y Dai, A Tokunaga, K Miki, K Yonenobu, T Ochi and K Noguchi. (2000). Activating transcription factor 3 (ATF3) induction by axotomy in sensory and motoneurons: a novel neuronal marker of nerve injury. Mol Cell Neurosci 15:170-182.

62. Seijffers R, CD Mills and CJ Woolf. (2007). ATF3 increases the intrinsic growth state of DRG neurons to enhance peripheral nerve regeneration. J Neurosci 27:7911-7920.

63. Campbell G, K Hutchins, J Winterbottom, G Grenningloh, AR Lieberman and PN Anderson. (2005). Upregulation of 
activating transcription factor 3 (ATF3) by intrinsic CNS neurons regenerating axons into peripheral nerve grafts. Exp Neurol 192:340-347.

64. Reid AJ, D Welin, M Wiberg, G Terenghi and LN Novikov. (2010). Peripherin and ATF3 genes are differentially regulated in regenerating and non-regenerating primary sensory neurons. Brain Res 1310:1-7.

65. Pearson AG, CW Gray, JF Pearson, JM Greenwood, MJ During and M Dragunow. (2003). ATF3 enhances c-Junmediated neurite sprouting. Brain Res Mol Brain Res 120: $38-45$.

66. Herdegen T, P Skene and M Bahr. (1997). The c-Jun transcription factor-bipotential mediator of neuronal death, survival and regeneration. Trends Neurosci 20:227-231.

67. Raivich G, M Bohatschek, CC Da, O Iwata, M Galiano, M Hristova, AS Nateri, M Makwana, L Riera-Sans, et al. (2004). The AP-1 transcription factor c-Jun is required for efficient axonal regeneration. Neuron 43:57-67.

68. Ruff CA, N Staak, S Patodia, M Kaswich, E Rocha-Ferreira, CC Da, S Brecht, M Makwana, X Fontana, et al. (2012). Neuronal c-Jun is required for successful axonal regeneration, but the effects of phosphorylation of its $\mathrm{N}$-terminus are moderate. J Neurochem 121:607-618.

69. Broude E, M McAtee, MS Kelley and BS Bregman. (1997). cJun expression in adult rat dorsal root ganglion neurons: differential response after central or peripheral axotomy. Exp Neurol 148:367-377.

70. Gold BG, T Storm-Dickerson and DR Austin. (1993). Regulation of the transcription factor c-JUN by nerve growth factor in adult sensory neurons. Neurosci Lett 154:129-133.

71. Lindwall C, L Dahlin, G Lundborg and M Kanje. (2004). Inhibition of c-Jun phosphorylation reduces axonal outgrowth of adult rat nodose ganglia and dorsal root ganglia sensory neurons. Mol Cell Neurosci 27:267-279.

72. Yuan Q, B Hu, Y Wu, TH Chu, H Su, W Zhang, KF So, Z Lin and $\mathrm{W}$ Wu. (2010). Induction of c-Jun phosphorylation in spinal motoneurons in neonatal and adult rats following axonal injury. Brain Res 1320:7-15.

73. Park BG, JS Lee, JY Lee, DY Song, SW Jeong and BP Cho. (2011). Co-localization of activating transcription factor 3 and phosphorylated c-Jun in axotomized facial motoneurons. Anat Cell Biol 44:226-237.

74. Yuan Q, H Su, J Guo, KY Tsang, KS Cheah, K Chiu, J Yang, WM Wong, KF So, et al. (2012). Decreased c-Jun expression correlates with impaired spinal motoneuron regeneration in aged mice following sciatic nerve crush. Exp Gerontol 47:329-336.

75. Hobson MI, CJ Green and G Terenghi. (2000). VEGF enhances intraneural angiogenesis and improves nerve regeneration after axotomy. J Anat $197 \mathrm{Pt}$ 4:591-605.

76. Kemp SW, S Syed, W Walsh, DW Zochodne and R Midha. (2009). Collagen nerve conduits promote enhanced axonal regeneration, schwann cell association, and neovascularization compared to silicone conduits. Tissue Eng Part A 15:1975-1988.

77. Conde-Green A, I Wu, I Graham, JJ Chae, CB Drachenberg, DP Singh, L Holton, III, S Slezak and J Elisseeff. (2013). Comparison of 3 techniques of fat grafting and cell-supplemented lipotransfer in athymic rats: a pilot study. Aesthet Surg J 33:713-721.

78. Matsuda K, KJ Falkenberg, AA Woods, YS Choi, WA Morrison and RJ Dilley. (2013). Adipose-derived stem cells promote angiogenesis and tissue formation for in vivo tissue engineering. Tissue Eng Part A 19:1327-1335.

Address correspondence to: Dr. Paul J. Kingham Section for Anatomy

Department of Integrative Medical Biology Umeå University SE-901 87 Umeå Sweden

E-mail: paul.kingham@umu.se

Received for publication June 23, 2013

Accepted after revision October 8, 2013

Prepublished on Liebert Instant Online XXXX XX, XXXX 